\title{
Temporal Variations and Controlling Factors of Nitrogen Export from an Artificially Drained Coastal Forest
}

\author{
Shiying Tian, ${ }^{*}{ }^{\dagger}$ Mohamed A. Youssef, ${ }^{\dagger}$ R. Wayne Skaggs, ${ }^{\dagger}$ Devendra M. Amatya, ${ }^{\ddagger}$ \\ and George M. Chescheir ${ }^{\dagger}$
}

${ }^{\dagger}$ Department of Biological and Agricultural Engineering, North Carolina State University, D. S. Weaver Laboratories, Campus Box
7625 , Raleigh, North Carolina 27695, United States
${ }^{\ddagger}$ U.S. Department of Agriculture Forest Service, Center for Forested Wetland Research, 3734 Highway 402, Cordesville, South
Carolina 29434, United States

Supporting Information

ABSTRACT: Nitrogen losses in drainage water from coastal forest plantations can constrain the long term sustainability of the system and could negatively affect adjacent nutrient sensitive coastal waters. Based on long-term (21 years) field measurements of hydrology and water quality, we investigated the temporal variations and controlling factors of nitrate and dissolved organic nitrogen (DON) export from an artificially drained coastal forest over various time scales (interannual, seasonal, and storm events). According to results of stepwise multiple linear regression analyses, the observed large interannual variations of nitrate flux and concentration from the drained forest were significantly $(p<0.004)$ controlled by annual mean water table depth, and annual drainage or precipitation. Annual precipitation and drainage were found to be dominant factors controlling variations of annual DON fluxes. Temporal trends of annual mean DON concentration could not be explained explicitly by climate or hydrologic factors. No significant difference was observed between nitrogen (both nitrate and DON) export during growing and nongrowing seasons. Nitrate exhibited distinguished export patterns during six

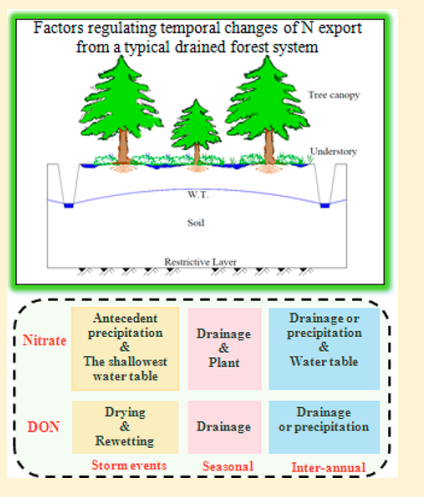
selected storm events. Peak nitrate concentrations during storm events were significantly $(p<$ 0.003) related to 30-day antecedent precipitation index and the minimum water table depth during individual events. The temporal variations of DON export within storm events did not follow a clear trend and its peak concentration during the storm events was found to be significantly $(p<0.006)$ controlled by the short-term drying and rewetting cycles.

\section{INTRODUCTION}

Nitrogen (N) export from forest ecosystems to surface waters is much smaller compared to agricultural land receiving $\mathrm{N}$ fertilizer. ${ }^{1}$ However, natural and anthropogenic disturbances to forest ecosystems, such as climate change, elevated atmospheric $\mathrm{N}$ deposition, and silvicultural practices, raise broad concerns about the potential rise in $\mathrm{N}$ leaching losses from forests. ${ }^{2}$ Quantifying temporal variations of $\mathrm{N}$ export from forests and exploring the underlying mechanisms are important to improve our understanding of the physical and biogeochemical processes regulating $\mathrm{N}$ fate and transport at the interface between forested lands and their adjacent surface waters.

The variations of nitrate and dissolved organic nitrogen (DON) export from upland forests over various temporal scales have been extensively investigated by hydrologists, ecologists, and environmental engineers. $^{3-8}$ In general, both nitrate and DON export from upland forests exhibit considerably large interannual variability, 9,10 which has been commonly linked to one or multiple climate factors, such as annual mean temperature, ${ }^{9,11}$ precipitation, ${ }^{11}$ soil freezing, ${ }^{10,11}$ and other natural or human disturbances such as hurricanes, fires, and forest harvesting. ${ }^{12}$ While only a few studies investigated longterm interannual variations of $\mathrm{DON}$ export from forest ecosystems, annual precipitation and runoff were found to be key factors controlling interannual DON fluxes in forest floor leachates ${ }^{13}$ and forest streams. ${ }^{9}$ Due to the seasonal changes of both biotic (plant and soil microbes retention) and abiotic (hydrological transport) factors, ${ }^{9}$ nitrate export from forests typically follows distinct seasonal trends characterized by higher concentrations and fluxes occurring during dormant seasons. ${ }^{9,14}$ In contrast, export of DON normally exhibits no significant seasonal changes. ${ }^{4,14}$ Nevertheless, few exceptions to the general trends of nitrate ${ }^{15}$ and $\mathrm{DON}^{16}$ export have been reported. A number of studies have also focused on $\mathrm{N}$ export dynamics from forests during individual storm events. Peak nitrate concentrations usually appear on the rising limb of hydrographs, which is referred to as the "nitrate flushing" phenomena. ${ }^{7,8,17}$ A somewhat similar trend was also observed for DON export dynamics during storm events. ${ }^{16-19}$

Existing studies on temporal variations and controlling factors of $\mathrm{N}$ export from forests have mainly focused on upland areas, and have largely ignored artificially drained lowland forests, despite their large areas and proximity to

\section{Received: April 2, 2012}

Revised: August 10, 2012

Accepted: August 19, 2012

Published: August 19, 2012 
nutrient sensitive waters. ${ }^{20}$ Artificially drained lowland forests are expected to be different from intensively studied upland forests with respect to the temporal variations and controlling factors of $\mathrm{N}$ export because of their distinct hydrological processes. Drained coastal forests are mainly characterized by soil matrix flow because of the combination of flat topography, high surface water storage, and artificial drainage ditches. Compared to outflow from higher gradient upland forests, which is dominated by rapid overland flow and lateral interflow, most of the outflow from drained lowland forests is moderate subsurface flow to drainage ditches. Artificial drainage ditches modify the hydrology of the lowland forest by providing improved subsurface drainage and acting as short circuits that enhance the subsurface movement of water and accompanying solutes offsite. The objectives of this study were to characterize and investigate the underlying controlling factors of the interannual, seasonal, and within-storm event variations of $\mathrm{N}$ (nitrate and DON) export from a typical lowland forest with improved drainage.

\section{MATERIALS AND METHODS}

Study Site. The study was conducted on a 25 ha loblolly pine (Pinus taeda L.) plantation located in the Atlantic Lower Coastal Plain of North Carolina, United States $\left(34^{\circ} 48^{\prime} \mathrm{N}, 76^{\circ}\right.$ $42^{\prime} \mathrm{W}$ ). The site is relatively flat (less than $0.1 \%$ slope) and has hydric soil. It is drained by four $1.2 \mathrm{~m}$ deep parallel lateral ditches dug at 100-m spacing. The loblolly pine trees, planted in 1974 at a density of 2100 trees ha $^{-1}$, were thinned in 1981 to 988 trees ha ${ }^{-1}$ and in 1988 to 370 trees ha ${ }^{-1}$. Nitrogen fertilizer was applied in early 1989 at a rate of $195 \mathrm{~kg}$ Urea-N ha ${ }^{-1}$. Thereafter, the site had not been disturbed for 20 years until it was clear-cut in 2009. The reader is referred to other studies $^{21-23}$ for a detailed description of the study site.

Data Collection and Sample Processing. Onsite collection of climatic, hydrologic, and water quality data has continued since early 1988. Measured climatic variables included precipitation $(\mathrm{mm})$, air temperature $\left({ }^{\circ} \mathrm{C}\right)$, relative humidity (\%), wind speed $\left(\mathrm{m} \mathrm{s}^{-1}\right)$ and direction, and solar and net radiation $\left(\mathrm{W} \mathrm{m}^{-2}\right)$. Drainage was estimated by water head that was measured every 6 min upstream from a $120^{\circ} \mathrm{V}$-notch weir installed at the outlet of the collector ditch. Water table depth (WTD) $(\mathrm{cm})$ was calculated as the mean of water levels that were measured every $15 \mathrm{~min}$ using two wells equipped with automatic water level recorders, located at two experimental plots midway between the inner field ditches of the site. Details of these measurements are given elsewhere. ${ }^{24}$

During the study period, automatic ISCO-2700 samplers were used to collect drainage water samples every $2 \mathrm{~h}$ during each storm event. From 1989 to 1994, four consecutive samples were mixed together to make one composite sample for every 8-h period, which produced three water quality samples per day. Since 1995, composite samples were collected at a 6-h interval and mixed together to make one water sample every 2 weeks for lab analysis. Additionally, grab samples were collected weekly or every 2 weeks during flow events for the whole study period. Filtered water samples were analyzed for concentrations of nitrate $\left(\left[\mathrm{NO}_{3}^{-1}\right]\right)$ and nitrite, ammonium, and total Kjeldahl nitrogen (TKN) according to U.S. Environmental Protection Agency methods. ${ }^{25}$ DON concentration ([DON]) was calculated as the difference between measured concentrations of TKN and ammonium. Detailed procedures of event sampling and lab analyses are documented elsewhere. ${ }^{24}$
Data Analysis. Ammonium was excluded from this study because it accounted for less than $1 \%$ of total $\mathrm{N}$ export from the study site. ${ }^{24}$ Analysis of $\mathrm{N}$ export in this study was mostly based upon composite sampling. Grab samples were only used when composite samples were unavailable during about 11 months throughout the entire 21 year data set. Annual and monthly mean concentrations were calculated by averaging concentrations measured from composite samples. Nitrate and DON fluxes during each 2-week interval were calculated as the product of the measured flow during the interval and the concentration based on the composite sample collected at the end of the interval. Monthly and annual fluxes were calculated by adding up the 2-week fluxes. Uncertainties with respect to solute flux estimations using infrequent sampling were reported in another study. ${ }^{26}$

Field measurements from 1991 to 2008 were used to investigate interannual $\mathrm{N}$ export dynamics. The first 2 years (1989 and 1990) were excluded to eliminate the effects of the 1989 fertilizer application on the analysis. A multiple stepwise linear regression procedure ${ }^{27}$ was used to identify subsets of climatic and hydrologic factors regulating annual $\mathrm{N}$ export from the drained forest. Model selection was based on Mallows' Cp criteria. ${ }^{27}$ Candidate variables were annual mean water table depth (MWTD), annual drainage flux (Q), annual mean temperature $(\mathrm{T})$, annual precipitation $(\mathrm{P})$, and annual net radiation $(\mathrm{R})$. To make regression equations meaningful, normalized values of dependent (concentration and flux) and independent variables were used to conduct the statistical analysis. The normalized values were obtained by dividing each value of the variable by its long-term mean during the whole study period. Collinearity diagnosis based on variance inflation factor (VIF) was conducted to avoid high correlations between selected factors used for the multiple stepwise linear regressions. Statistical analyses were carried out using the procedures GLMSELECT of the SAS statistical package (SAS Institute, Cary, NC).

Seasonal variations of $\mathrm{N}$ export from the study site were investigated by analyzing monthly mean concentration and flux for the whole study period. Months with no drainage were excluded from the analysis. Growing season of loblolly pine in southeastern United States was defined as the period from March to November. ${ }^{28}$ Two tailed student $t$-test was used to determine the significance (at $\alpha=0.05$ ) of difference between $\mathrm{N}$ export during growing and nongrowing seasons.

Six single storm events, which occurred in different seasons from 1992 to 1994, were selected to quantify the short-term variations of $\mathrm{N}$ export. Factors characterizing the antecedent soil moisture condition and individual storm event were used as candidate factors controlling peak nitrate and DON concentrations within storm events. Antecedent soil moisture condition is characterized by 30-day antecedent mean water table depth $\left(\mathrm{MWTD}_{30}\right)$ and 30-day antecedent precipitation index $\left(\mathrm{API}_{30}\right){ }^{5,29,30}$ The $\mathrm{API}_{30}$ is defined as

$$
\mathrm{API}_{30}=\sum_{i=1}^{30} \frac{P_{i}}{i}
$$

where $P_{i}(\mathrm{~mm})$ is the total precipitation on the $i$ th day before the event. Uncertainties of using $\mathrm{API}_{30}$ to represent antecedent soil moisture condition were reported elsewhere. ${ }^{5,29,30}$ Key storm characteristics (Table SI-2 in the Supporting Information) included in the analysis are peak precipitation intensity $\left(\mathrm{cm} \mathrm{hr}^{-1}\right)$, total precipitation amount $(\mathrm{mm})$, the minimum 
water table depth $(\mathrm{cm})$ during the event $\left(\mathrm{WTD}_{\min }\right)$, peak drainage rate $\left(\mathrm{m}^{3} \mathrm{~s}^{-1}\right)$, and time to peak drainage $(\mathrm{hr})$. Strength (Person correlation coefficient) and significance $(\alpha=0.05)$ of relationships between these selected factors and peak solute concentration are reported.

\section{RESULTS AND DISCUSSION}

Annual Dynamics of Nitrogen Export. Similar to results obtained from upland forests in northeastern ${ }^{10}$ and southeastern $^{31}$ United States, and central Canada, ${ }^{11}$ annual nitrate and DON export showed considerably large interannual variation over the study period from 1991 to 2008 (Figure 1). The annual mean $\left[\mathrm{NO}_{3}^{-1}\right]$ ranged from $0.08 \mathrm{mg} \mathrm{L}^{-1}$ in 2001

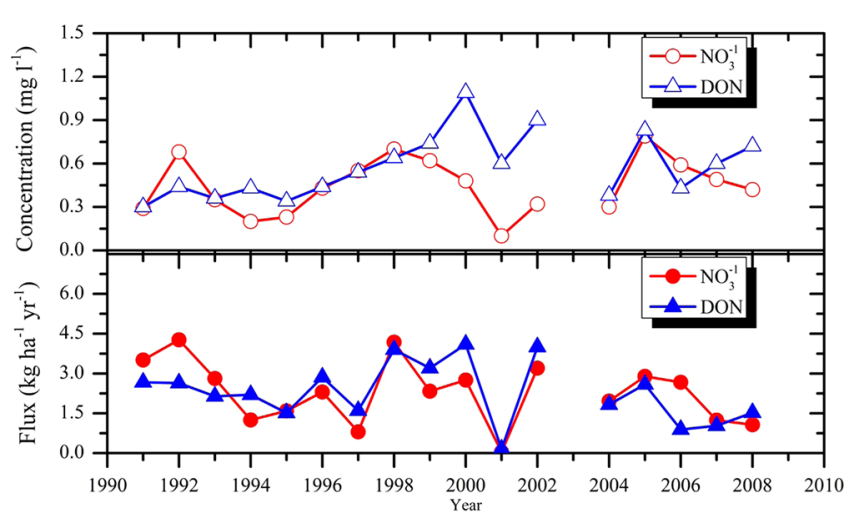

Figure 1. International dynamics of annual mean concentrations (top figure) and fluxes (bottom figure) of nitrate and DON from the drained forested site. to $0.76 \mathrm{mg} \mathrm{L}^{-1}$ in 2005 with a mean of $0.50 \mathrm{mg} \mathrm{L}^{-1}$ and a standard deviation (SD) of $0.28 \mathrm{mg} \mathrm{L}^{-1}$ (Figure 1). The smallest annual nitrate flux from the watershed was $0.04 \mathrm{~kg} \mathrm{ha}^{-1}$ in 2001 and the highest one was $4.4 \mathrm{~kg} \mathrm{ha}^{-1}$ in 1992. The longterm mean annual nitrate flux was $2.6 \mathrm{~kg} \mathrm{ha}^{-1}$ and the SD was $1.48 \mathrm{~kg} \mathrm{ha}^{-1}$. Mean annual [DON] ranged from $0.32 \mathrm{mg} \mathrm{L}^{-1}$ in 1991 to $1.09 \mathrm{mg} \mathrm{L}^{-1}$ in 2000 with a mean and a SD of 0.65 and $0.32 \mathrm{mg} \mathrm{L}^{-1}$, respectively. Annual DON flux was highest $(4.2 \mathrm{~kg}$ $\left.\mathrm{ha}^{-1}\right)$ in 2000 and was lowest $\left(0.03 \mathrm{~kg} \mathrm{~N} \mathrm{ha}^{-1}\right)$ in 2001. Mean annual DON flux was $2.5 \mathrm{~kg} \mathrm{ha}^{-1}$ and the SD was $1.58 \mathrm{~kg} \mathrm{ha}^{-1}$.

According to the collinearity diagnosis, annual precipitation and drainage showed strong collinear relationship $\left(R^{2}=0.86\right.$ and VIF > 6.0). This suggests that only one of the two factors can be used for the stepwise multiple regression analysis. The full regression equations including all five candidate factors (MWTD, T, R, P, or Q) are listed in Table SI-1. Comparisons between field measurements and predicted solute concentrations and fluxes using the "best-fit" regression equations are also shown in Figure 2. Coefficients of determination $\left(R^{2}\right)$ of full regression equations in Table SI-1 are comparable to those of selected "best-fit" regression equations in Figure 2, suggesting that selected factors based on Mallows' Cp criteria were reasonable.

Water table depth and annual precipitation or drainage are the two key factors significantly regulating temporal changes of annual $\left[\mathrm{NO}_{3}^{-1}\right]$ and export (Table SI-1, Figure $2 \mathrm{~A}$ and $\mathrm{C}$ ). Estimated annual mean $\left[\mathrm{NO}_{3}^{-1}\right]$ and fluxes using the regression equations with MWTD and precipitation were in good agreement with field measurements (Figure 2A and C). Daily WTDs were less than 50 and $20 \mathrm{~cm}$ during $32.5 \%$ and $4.6 \%$ of the whole study period, respectively. There was a significant and negative relationship between MWTD and annual mean
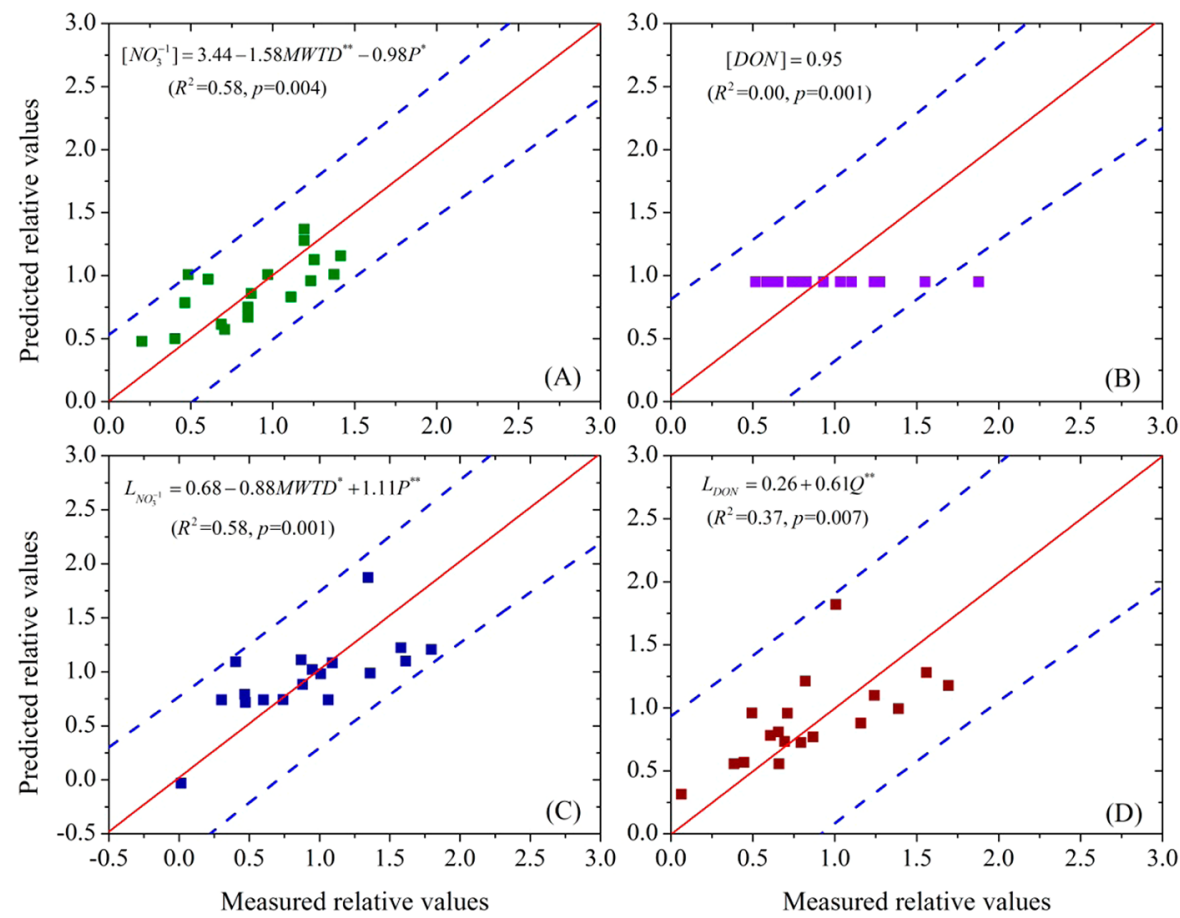

Figure 2. Comparisons between measured and predicted nitrogen export on an annual basis with $95 \%$ prediction confidence intervals as covered by dashed lines. (A) Annual mean nitrate concentration ( $\left.\left[\mathrm{NO}_{3}^{-1}\right]\right)$; (B) annual mean DON concentration ([DON]); (C) annual nitrate loading $\left(L_{\mathrm{NO}_{3}^{-1}}\right)$; (D) annual DON loading $\left(L_{\mathrm{DON}}\right)$. The calibrated equations using selected parameters based on the Mallows' $\mathrm{C}_{\mathrm{p}}$ criteria are listed under each figure. $\mathrm{T}$ is annual mean temperature, $\mathrm{R}$ is annual radiation, $\mathrm{Q}$ is annual drainage, MWTD is annual mean water table depth, $\mathrm{P}$ is annual precipitation. The asterisks indicates significance level of individual factor $(* p<0.05, * * p<0.01, * * * p 0.005, n=18$ for nitrate, $n=17$ for DON). 


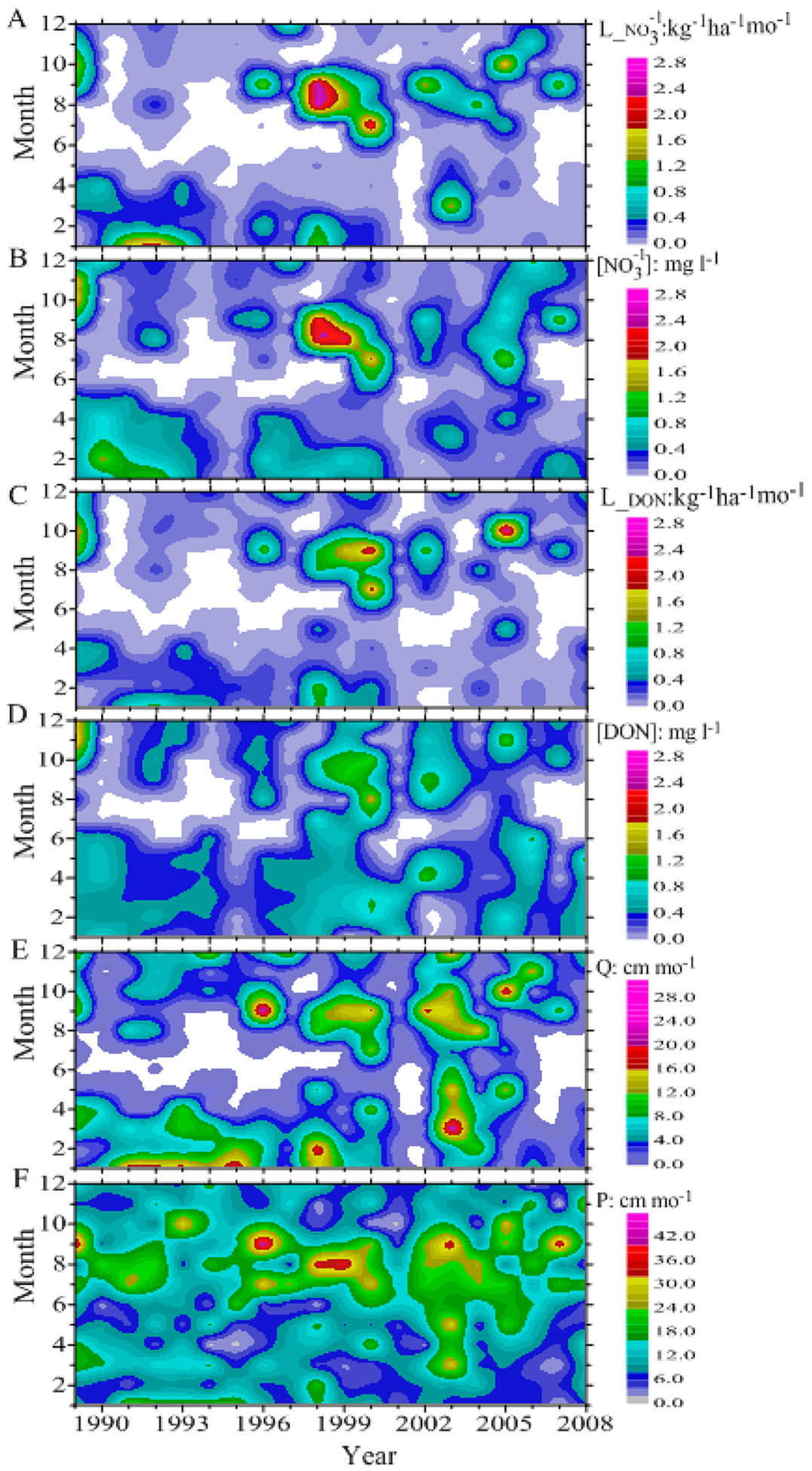

Figure 3. Seasonality of nitrogen export and hydrological dynamics represented by monthly values from 1989 to 2008. (A) Monthly nitrate flux $\left(\mathrm{L}_{-} \mathrm{NO}_{3}^{-1}\right)$; (B) monthly mean nitrate concentration $\left(\left[\mathrm{NO}_{3}^{-1}\right]\right)$; (C) monthly dissolved organic nitrogen flux (L_DON); (D) monthly mean DON concentration $([\mathrm{DON}])$; (E) measured monthly drainage (Q); (F) precipitation $(\mathrm{P})$.

$\left[\mathrm{NO}_{3}^{-1}\right](p=0.009)$, as well as between MWTD and annual nitrate flux $(p=0.03)$, suggesting that shallow water table could lead to higher annual mean $\left[\mathrm{NO}_{3}^{-1}\right]$ and export. This is because shallow water table in these drained soils not only indicates high hydraulic gradient and drainage flux, but also increases the vulnerability of soil nitrate, which mainly accumulates in top soil profile, to be leached out. Moreover, smaller MWTD indicates higher soil moisture in the vadose zone, which favors net mineralization and nitrate availability in the soil profile. ${ }^{8}$ The similar effects of water table dynamics on nitrate export were observed for drained agricultural land with relatively flat topography. ${ }^{32}$ Previous studies on upland forests rarely investigated impacts of WTD on nitrate losses.

Annual precipitation or drainage flux showed positive impacts on annual nitrate fluxes $(p<0.008)$, but negative impacts on annual mean $\left[\mathrm{NO}_{3}^{-1}\right](p=0.04)$ because of dilution 

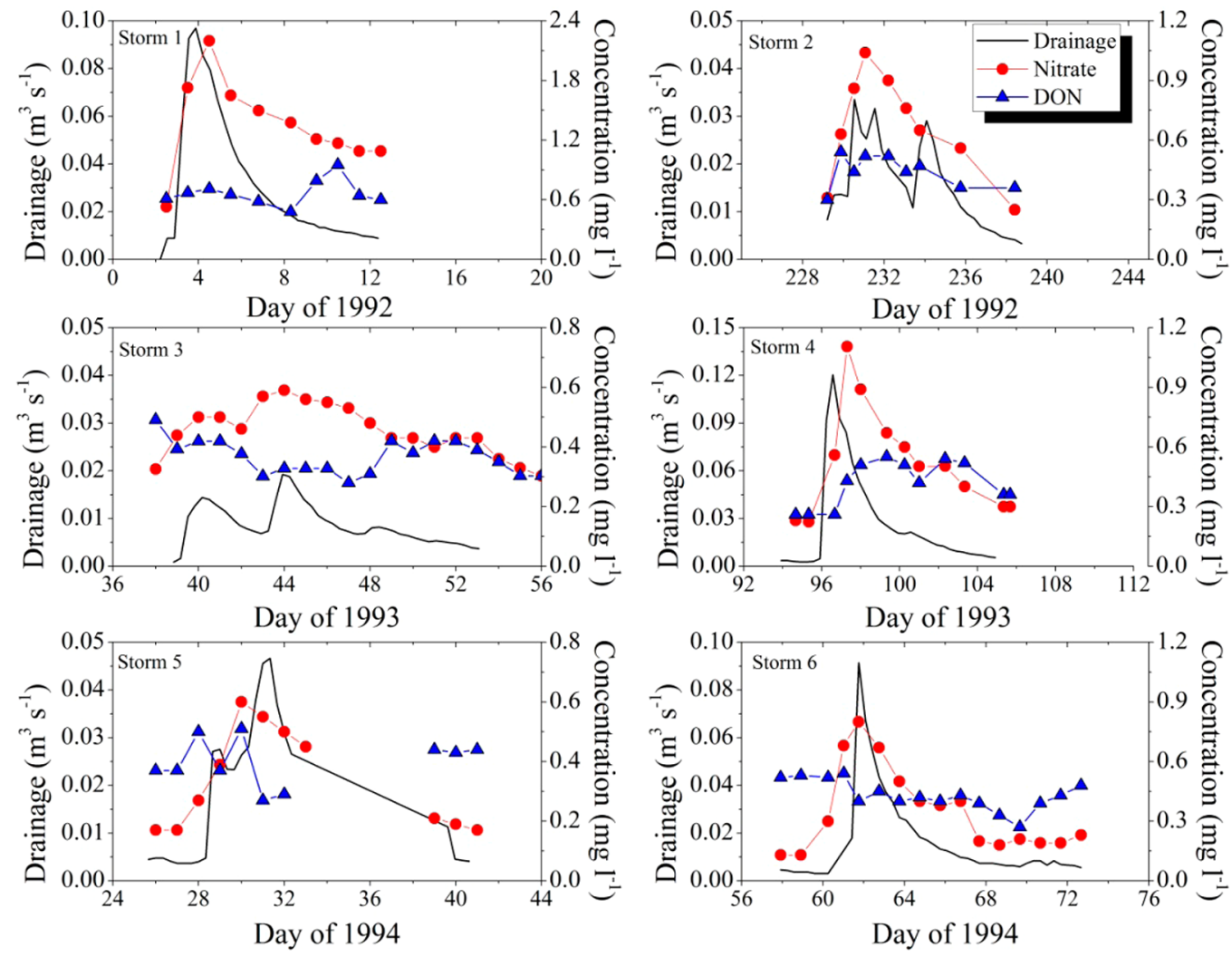

Figure 4. Hydrograph (solid line) and concentrations $\left(\mathrm{mg} \mathrm{L}^{-1}\right)$ of nitrate (solid line with circle) and DON (line with triangle) during the six storms selected between 1992 and 1994.

effects. The long-term measurements of precipitation and drainage were reported in other publications. ${ }^{20,23,33}$ The positive impacts of annual precipitation and/or runoff on annual nitrate fluxes were reported in several studies of upland forests. ${ }^{9,34,35}$ The negative impacts of annual runoff on annual mean $\left[\mathrm{NO}_{3}^{-1}\right]$ was also reported. ${ }^{19}$ Because of its effects on soil $\mathrm{N}$ mineralization, ${ }^{8,9}$ temperature has been regarded as one of the main factors influencing the temporal dynamics of annual nitrate export. ${ }^{10,11,36}$ However, we did not find significant impacts of annual mean temperature on nitrate export. This is mainly caused by the relatively low interannual fluctuations of annual mean temperature, as indicated by the low $\mathrm{SD}$ of $0.5^{\circ} \mathrm{C}$, compared to the long-term mean of $16.4{ }^{\circ} \mathrm{C}$.

Statistical analysis indicated that annual drainage (Figure 2D) was strongly related with DON fluxes with significant relationship. This result was comparable to findings of several studies in temperate upland forests. ${ }^{13,18,19}$ However, none of the factors included in the analysis was identified as statistically significant variable regulating the interannual variation of [DON] (SI-1, Figure 2B). The unclear relationship between DON export in forest streams and a single climatic or hydrologic factor was also reported for a number of upland temperate forests. ${ }^{13}$ This is mainly because none of the candidate factors can quantify the dominant role of adsorption/ desorption processes in regulating the release of DON from soil. However, a few studies in upland forests showed that drainage posed a positive impact on mean annual $[\mathrm{DON}] .{ }^{18}$

Seasonal Dynamics. Large temporal variations were observed in monthly $\left[\mathrm{NO}_{3}^{-1}\right]$ (mean $=0.5 \mathrm{mg} \mathrm{L}{ }^{-1}$ and $\mathrm{SD}=$ $0.46 \mathrm{mg} \mathrm{L}^{-1}$ ) and flux (mean $=0.22 \mathrm{~kg} \mathrm{ha}^{-1} \mathrm{mo}^{-1}$ and SD $=0.5$ $\mathrm{kg} \mathrm{ha}^{-1} \mathrm{mo}^{-1}$ ). High nitrate fluxes and concentrations occurred in all seasons except during late spring and early summer
(Figure 3A and B) when plant uptake depletes most of the nitrate-N in the shallow soil profile. Monthly DON flux (Figure 3C) and concentration (Figure 3D) exhibited a seasonal trend similar to that of nitrate but with smaller seasonal variations. Mean and SD of monthly [DON] were 0.64 and $0.67 \mathrm{mg} \mathrm{L}^{-1}$, while mean and SD of monthly DON flux were 0.21 and 0.35 $\mathrm{kg} \mathrm{ha}^{-1} \mathrm{mo}^{-1}$. The clear overlap of the "hot" moments of elevated nitrate and DON export during large drainage period (Figure 3E) indicates that monthly drainage is a strong predictor for monthly nitrate $\left(R^{2}=0.63, p=0.02\right)$ and DON $\left(R^{2}=0.56, p=0.03\right)$ export. However, there is a lack of correlation between monthly drainage and $\left[\mathrm{NO}_{3}^{-1}\right]\left(R^{2}=0.26\right.$, $p=0.21)$ or $[\mathrm{DON}]\left(R^{2}=0.15, p=0.23\right)$. This is because small to medium precipitation events (e.g., Aug to Sept 1998 and 1999, Oct 2005) usually trigger leaching losses of nitrate and DON accumulated in the top soil profile, while large tropical storm events of the summer often dilute the concentration (e.g., hurricane Fran with $447 \mathrm{~mm}$ of rain in Sept 1996, and the abnormal Atlantic hurricane season in 2003).

There is no significant difference $(p=0.3, d f=146)$ between the $\left[\mathrm{NO}_{3}^{-1}\right]$ during growing and nongrowing seasons of 1989 to 2008. Nevertheless, monthly mean $\left[\mathrm{NO}_{3}^{-1}\right]$ was found to be significantly higher (marginally) $(p=0.07, d f=33)$ during nongrowing seasons than during growing seasons of 1989 to 1994. This shift of seasonality of nitrate export could be attributed to a couple of causes. The mean drainage amount during the growing seasons of the years 1989-1994 was 184 $\mathrm{mm}$, much lower than the mean drainage during the growing seasons for the whole study period $(264 \mathrm{~mm})$. The relatively drier growing seasons during 1989-1994 (Figure 3E and F) could be a main cause since soil moisture is usually the primary constraint for $\mathrm{N}$ mineralization in temperate forests. ${ }^{5}$ Mean- 

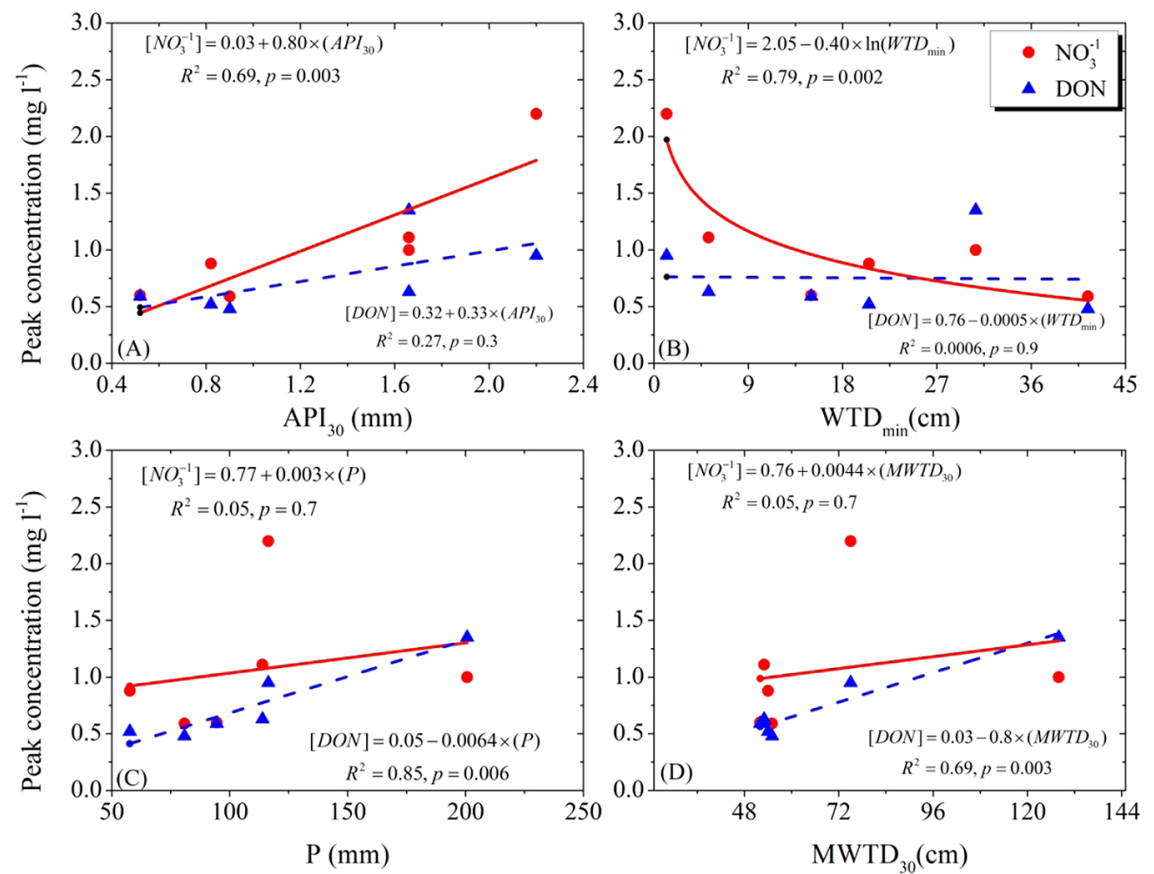

Figure 5. Relationships between 30-day antecedent precipitation index $\left(\mathrm{API}_{30}\right)(\mathrm{A})$, minimum water table depth $\left(\mathrm{WTD}_{\min }\right)(\mathrm{B})$, event precipitation (P) (C), and 30-day mean water table depth $\left(M_{W T D}\right)(D)$ and peak concentration for both nitrate and DON of the selected six storm events.

while, the decline of loblolly pine growth rate, usually starting at tree age between 15 and 20 years (around 1994 in the study site) in Southeastern United States, ${ }^{37}$ might weaken the dominant role of plant uptake in regulating seasonal variations of nitrate export. The impact of stand succession on nitrate export has also been observed in some upland forests. ${ }^{31,38}$ In contrast to nitrate, we did not find similar shift of seasonal export dynamics of DON from the lowland forest over the study period.

Monthly $[\mathrm{DON}]$ and DON fluxes during growing seasons were also not significantly different $(p>0.25, d f=131)$ from those during nongrowing seasons. The absence of significant difference of DON export during growing and nongrowing seasons observed in this study and other studies ${ }^{9,16,17,39}$ can be partially explained by two main reasons. First, DON is less accessible and hard to be assimilated directly by plants; thus it is less controlled by seasonal changes in plant uptake. ${ }^{40}$ Second, the DON release is mainly controlled by soil sorption, which does not exhibit seasonal change. ${ }^{40-42}$

Nitrogen Export at the Storm-Event Scale. Nitrate Export Dynamics during Storm Events. Initial $\left[\mathrm{NO}_{3}^{-1}\right]$ prior to the rising limbs of storm hydrographs ranged from 0.13 to $0.53 \mathrm{mg} \mathrm{L}^{-1}$ (the mean concentration $=0.29 \mathrm{mg} \mathrm{L}^{-1}$ ) with the lowest concentration occurred during the March 1994 storm (Figure 4). During all six storms, $\left[\mathrm{NO}_{3}^{-1}\right]$ initially increased as the drainage rate increased until it reached peak concentration prior to or after the appearance of peak drainage, followed by a decline in concentration during the hydrological recession periods. This decline in $\left[\mathrm{NO}_{3}^{-1}\right]$ during the falling limbs of the hydrographs was gradual and usually took 6-14 days for the $\left[\mathrm{NO}_{3}^{-1}\right]$ to return to their initial values prior to storm events (Figure 4). Peak $\left[\mathrm{NO}_{3}^{-1}\right]$ ranged from 0.59 to $2.2 \mathrm{mg} \mathrm{L}^{-1}$ and these peak concentrations were 2-4 times the corresponding initial concentrations (Figure 4). Peak $\left[\mathrm{NO}_{3}^{-1}\right]$ occurred after peak hydrograph of storms 1,2 , and 4 . Because of limitations of our sampling method, it is difficult to conclude with confidence that peak concentrations occurred prior to peak drainage for storms 3 and 6, which had lag times between peak $\left[\mathrm{NO}_{3}^{-1}\right]$ and peak hydrograph of less than $8 \mathrm{~h}$. Only the fifth storm event clearly displayed the so-called "nitrate flushing" phenomenon because peak $\left[\mathrm{NO}_{3}^{-1}\right]$ occurred 1.5 days prior to the peak drainage. The lack of nitrate "flushing" phenomenon in other five selected storm events is contrary to other studies. ${ }^{4,30}$ This probably resulted from the relatively rapid hydrological response to precipitation events (SI-2) in the study site due to the existence of the drainage ditches and the small size of the watershed. Previous studies showing nitrate "flushing" phenomenon usually had relatively longer time to peak drainage. For instance, time to peak drainage was about 10 and 7 days in some upland forest watersheds with large drainage area (usually $>100 \mathrm{ha}$ ), ${ }^{4,30}$ comparable to 5 days for the storm exhibiting "flushing" phenomenon (Storm 5, Figure 4). In contrast, studies that did not report nitrate "flushing" usually reported relatively short time to peak drainage such as less than 2 days (Storms 1, 2, and 4) in our study, less than 1 day, ${ }^{6}$ and less than half a day. ${ }^{8}$ An exception was McHale et al. ${ }^{5}$ who found nitrate "flushing" occurred even at less than 1 day time to peak drainage.

Only $\mathrm{API}_{30}$ and $\mathrm{WTD}_{\text {min }}$ during an individual storm event have significant effects on peak $\left[\mathrm{NO}_{3}^{-1}\right]$ for the six storm events (Figure $5 \mathrm{~A}$ and $\mathrm{B}$ ). The significant positive linear relationship between $\mathrm{API}_{30}$ and the peak $\left[\mathrm{NO}_{3}^{-1}\right]$ (Figure $5 \mathrm{~A}$ ) suggests that soil moisture is a key factor regulating the peak $\left[\mathrm{NO}_{3}^{-1}\right]$ during storm events. Compared to the $\mathrm{MWTD}_{30}, \mathrm{API}_{30}$ was found to be a better indicator of antecedent soil moisture (Figure 5A).

The logarithmic relationship between $\mathrm{WTD}_{\min }$ and peak $\left[\mathrm{NO}_{3}^{-1}\right]$ is strong and significant (Figure $5 \mathrm{~B}$ ). Peak $\left[\mathrm{NO}_{3}^{-1}\right]$ was much higher when the peak water table reached the soil surface, and it dropped quickly once the peak water table starts to decline. The negative effect of the $\mathrm{WTD}_{\min }$ on $\left[\mathrm{NO}_{3}^{-1}\right]$ further supported our explanation and conclusions obtained from analysis on annual nitrate export. The logarithmic rather than 
linear relationship between $\left[\mathrm{NO}_{3}^{-1}\right]$ and the $\mathrm{WTD}_{\min }$ during the storm event is consistent with the widely observed exponential decline of soil nitrate with depth. ${ }^{43}$

DON Export Dynamics during Storm Events. Unlike nitrate, the fluctuations of the [DON] during the six storms were relatively smaller (Figure 4 ). The maximum [DON] of these storms ranged from 0.48 to $1.35 \mathrm{mg} \mathrm{L}^{-1}$ and were less than 2.3 times the lowest [DON] before each storm. The highest concentration of DON occurred prior to or after the peak drainage and did not follow hydrograph patterns as nitrate did.

We did not find clear temporal trends of DON export during storm events (Figure 4), in contrast to previous studies that found $[\mathrm{DON}]$ consistently peaked at or before peak drainage during storm events in upland forests. ${ }^{16-19}$ Overland flow and shallow subsurface interflow were found to be dominant flow paths for transporting soil DON to streams in upland forests. ${ }^{16,17,19}$ The lack of clear temporal trends in our study was mainly attributed to the absence of lateral water flow paths either through overland flow or interflow. The DON in soilwater can only be transported through soil matrix and macropore flow, during which the rate limited soil desorption/adsorption process was the controlling factor. ${ }^{44}$

In contrast to nitrate, the $\mathrm{API}_{30}$ was not a strong indicator for maximum [DON] for these storms as indicated by the weak linear relationship in Figure 5A. The $\mathrm{WTD}_{\min }$ had no effect on peak $[\mathrm{DON}]$ as shown in Figure $5 \mathrm{~B}\left(R^{2}=0.0006\right.$ and $p=$ 0.96). Both $\mathrm{MWTD}_{30}$ and precipitation during storm events displayed significant positive effects on peak [DON] during storm events (Figure 5C and D), suggesting the drying (large $\mathrm{MWTD}_{30}$ ) and rewetting (precipitation) events increased DON export from the drained forest. It is also known that drying and rewetting of soils could temporarily result in a pronounced increase in soil soluble organic compounds. ${ }^{40}$ The well-recognized physiological stress for the microbial community and destruction of soil aggregates caused by drying and rewetting events were common explanations of increased DON losses following these events. ${ }^{45}$

\section{IMPLICATIONS OF THIS STUDY}

Based on 21-year field measurements of weather, hydrology, and water quality from an artificially drained pine plantation, this study elucidated the temporal dynamics of $\mathrm{N}$ (nitrate and DON) export from a typical managed lowland forest and investigated the underlying controlling factors. Results from this study improved our understanding of $\mathrm{N}$ export from lowland forests by highlighting both similarities and differences between $\mathrm{N}$ export from a typical drained lowland forest and other upland forests. The observed different temporal dynamics (e.g., lack of temporal trend of [DON] during storm events) and controlling factors (e.g., impacts of WTD on nitrate export) of $\mathrm{N}$ export from this artificially drained lowland forest implied the dominant role of hydrologic paths in regulating $\mathrm{N}$ losses from forest ecosystems. Findings from this study are of important implication for adjusting the timing of $\mathrm{N}$ fertilizer application in the lowland pine plantations to minimize $\mathrm{N}$ leaching losses. This study also points to the need for further investigations of $\mathrm{N}$, especially $\mathrm{DON}$, export from lowland forests to extend and refine our findings.

Among climatic factors, precipitation was found to be a key driver regulating $\mathrm{N}$ export from both upland and lowland forest ecosystems. The projected future changes of precipitation pattern in the southeastern United States ${ }^{46}$ will influence the temporal trend of $\mathrm{N}$ export from lowland drained forests. Specifically, the seasonal shift of precipitation trend (increasing autumn precipitation and decreasing spring and summer precipitation) may fundamentally change seasonal export dynamics of both nitrate and DON from lowland forests. Since drying and rewetting cycling is a key factor regulating DON export, future DON export from these drained lowland forests may be accelerated due to the projected increase of frequency, duration, and intensity of drought events, as well as increasing intensities of Atlantic hurricanes. ${ }^{46}$ However, the long-term impacts of the projected climate change on $\mathrm{N}$ cycling in these lowland forests needs further investigations.

\section{ASSOCIATED CONTENT}

\section{Supporting Information}

Multiple linear regressions between nitrogen export in drainage and all candidate climatic and hydrological variables; characteristics of the six selected storm events. This information is available free of charge via the Internet at http://pubs.acs.org.

\section{AUTHOR INFORMATION}

\section{Corresponding Author}

*E-mail: stian.tsy@gmail.com, stian@ncsu.edu.

\section{Notes}

The authors declare no competing financial interest.

\section{ACKNOWLEDGMENTS}

This work was supported in part by funds provided by the USDA Forest Service, Southern Research Station, and Center for Forested Wetlands Research (Federal Grant 06-CA-11330 135-173) through funds provided by the National Council for Air \& Stream Improvement (NCASI), Inc. Thanks to Dr. Dickey in the Department of Statistics of NCSU for his consulting service on the statistical analysis in this study.

\section{REFERENCES}

(1) Galloway, J. N.; Aber, J. D.; Erisman, J. W.; Seitzinger, S. P.; Howarth, R. W.; Cowling, E. B.; Cosby, B. J. The nitrogen cascade. Bioscience 2003, 53 (4), 341-356.

(2) Howarth, R. W.; Billen, G.; Swaney, D.; Townsend, A.; Jaworski, N.; Lajtha, K.; Downing, J. A.; Elmgren, R.; Caraco, N.; Jordan, T.; Berendse, F.; Freney, J.; Kudeyarov, V.; Murdoch, P.; Zhu, Z. L. Regional nitrogen budgets and riverine N\&P fluxes for the drainages to the North Atlantic Ocean: Natural and human influences. Biogeochemistry 1996, 35 (1), 75-139.

(3) Creed, I. F.; Band, L. E.; Foster, N. W.; Morrison, I. K.; Nicolson, J. A.; Semkin, R. S.; Jeffries, D. S. Regulation of nitrate-N release from temperate forests: A test of the $\mathrm{N}$ flushing hypothesis. Water Resour. Res. 1996, 32 (11), 3337-3354.

(4) Creed, I. F.; Band, L. E. Export of nitrogen from catchments within a temperate forest: Evidence for a unifying mechanism regulated by variable source area dynamics. Water Resour. Res. 1998, 34 (11), 3105-3120.

(5) McHale, M. R.; McDonnell, J. J.; Mitchell, M. J.; Cirmo, C. P. A field-based study of soil water and groundwater nitrate release in an Adirondack forested watershed. Water Resour. Res. 2002, 38 (4).

(6) Inamdar, S. P.; O'Leary, N.; Mitchell, M. J.; Riley, J. T. The impact of storm events on solute exports from a glaciated forested watershed in western New York, USA. Hydrol. Processes 2006, 20 (16), 3423-3439.

(7) Weiler, M.; McDonnell, J. R. J. Testing nutrient flushing hypotheses at the hillslope scale: A virtual experiment approach. $J$. Hydrol. 2006, 319 (1-4), 339-356.

(8) Rusjan, S.; Brilly, M.; Mikos, M. Flushing of nitrate from a forested watershed: An insight into hydrological nitrate mobilization 
mechanisms through seasonal high-frequency stream nitrate dynamics.

J. Hydrol. 2008, 354 (1-4), 187-202.

(9) Dittman, J. A.; Driscoll, C. T.; Groffman, P. M.; Fahey, T. J. Dynamics of nitrogen and dissolved organic carbon at the Hubbard Brook Experimental Forest. Ecology 2007, 88 (5), 1153-1166.

(10) Fitzhugh, R. D.; Likens, G. E.; Driscoll, C. T.; Mitchell, M. J.; Groffman, P. M.; Fahey, T. J.; Hardy, J. P. Role of soil freezing events in interannual patterns of stream chemistry at the Hubbard Brook experimental forest, New Hampshire. Environ. Sci. Technol. 2003, 37 (8), 1575-1580.

(11) Watmough, S. A.; Eimers, M. C.; Aherne, J.; Dillon, P. J. Climate effects on stream nitrate concentrations at 16 forested catchments in south central Ontario. Environ. Sci. Technol. 2004, 38 (8), 2383-2388.

(12) Goodale, C. L.; Aber, J. D.; Vitousek, P. M. An unexpected nitrate decline in New Hampshire streams. Ecosystems 2003, 6 (1), $75-86$.

(13) Michalzik, B.; Kalbitz, K.; Park, J. H.; Solinger, S.; Matzner, E. Fluxes and concentrations of dissolved organic carbon and nitrogen - a synthesis for temperate forests. Biogeochemistry 2001, 52 (2), 173205.

(14) Goodale, C. L.; Aber, J. D.; McDowell, W. H. The long-term effects of disturbance on organic and inorganic nitrogen export in the White Mountains, New Hampshire. Ecosystems 2000, 3 (5), 433-450.

(15) Ohte, N.; Tokuchi, N.; Fujimoto, M. Seasonal patterns of nitrate discharge from forested catchments: information derived from Japanese case studies. Geogr. Compass 2010, 4 (9), 1358-1376.

(16) Hagedorn, F.; Bucher, J. B.; Schleppi, P. Contrasting dynamics of dissolved inorganic and organic nitrogen in soil and surface waters of forested catchments with Gleysols. Geoderma 2001, 100 (1-2), 173-192.

(17) Inamdar, S. P.; Mitchell, M. J., Storm event exports of dissolved organic nitrogen (DON) across multiple catchments in a glaciated forested watershed. J. Geophys. Res.-Biogeosci. 2007, 112 (G2).

(18) McHale, M. R.; Mitchell, M. J.; McDonnell, J. J.; Cirmo, C. P. Nitrogen solutes in an Adirondack forested watershed: Importance of dissolved organic nitrogen. Biogeochemistry 2000, 48 (2), 165-184.

(19) Vanderbilt, K. L.; Lajtha, K.; Swanson, F. J. Biogeochemistry of unpolluted forested watersheds in the Oregon Cascades: Temporal patterns of precipitation and stream nitrogen fluxes. Biogeochemistry 2003, 62 (1), 87-117.

(20) Amatya, D. M.; Skaggs, R. W. Long-term hydrology and water quality of a drained pine plantation in North Carolina. Trans. ASABE 2011, 54 (6), 2087-2098.

(21) Mccarthy, E. J.; Skaggs, R. W.; Farnum, P. Experimentaldetermination of the hydrologic components of a drained forest watershed. Tran. ASAE 1991, 34 (5), 2031-2039.

(22) Amatya, D. M.; Skaggs, R. W.; Gregory, J. D. Effects of controlled drainage on the hydrology of drained pine plantations in the North Carolina coastal plain. J. Hydrol. 1996, 181 (1-4), 211232.

(23) Tian, S.; Youssef, M. A.; Skaggs, R. W.; Amatya, D.; Chescheir, G. M. DRAINMOD-FOREST: Integrated modeling of hydrology, soil carbon and nitrogen dynamics, and plant growth for drained forests. $J$. Environ. Qual. 2012, 41, 964-782.

(24) Amatya, D. M.; Gilliam, J. W.; Skaggs, R. W.; Lebo, M. E.; Campbell, R. G. Effects of controlled drainage on forest water quality. J. Environ. Qual. 1998, 27 (4), 923-935.

(25) USEPA. Methods for Chemical Analysis of Water and Wastes; EPA-600/4-79-020; Washington, DC, 1983.

(26) Chescheir, G. M.; Birgand., F.; Tian, S.; Youssef, M. A.; Amatya, D. M. The Effect of Sampling Frequency on the Accuracy of Nitrogen Load Estimates from Drained Loblolly Pine Plantations in Eastern North Carolina. In Proceedings of ASABE's 9th International Drainage Symposium, Québec City, Canada, June 13-17, 2010; pp 516-527.

(27) Ott, R. L., Longnecker, M. L. An Introduction to Statistical Methods and Data Analysis, 6th ed.; Cengage Learning, 2008.

(28) Nedlo, J. E.; Martin, T. A.; Vose, J. M.; Teskey, R. O. Growing season temperatures limit growth of loblolly pine (Pinus taeda L.) seedlings across a wide geographic transect. Trees-Struct. Funct. 2009, 23 (4), 751-759.

(29) Inamdar, S. P.; Mitchell, M. J. Hydrologic and topographic controls on storm-event exports of dissolved organic carbon (DOC) and nitrate across catchment scales. Water Resour. Res. 2006, 42 (3).

(30) Christopher, S. F.; Mitchell, M. J.; McHale, M. R.; Boyer, E. W.; Burns, D. A.; Kendall, C. Factors controlling nitrogen release from two forested catchments with contrasting hydrochemical responses. Hydrol. Processes 2008, 22 (1), 46-62.

(31) Swank, W. T.; Vose, J. M. Long-term nitrogen dynamics of Coweeta forested watersheds in the southeastern United States of America. Global Biogeochem. Cycles 1997, 11 (4), 657-671.

(32) Molenat, J.; Gascuel-Odoux, C.; Ruiz, L.; Gruau, G. Role of water table dynamics on stream nitrate export and concentration in agricultural headwater catchment (France). J. Hydrol. 2008, 348 (34), 363-378.

(33) Tian, S. Y.; Youssef, M. A.; Skaggs, R. W.; Amatya, D. M.; Chescheir, G. M. Modeling water, carbon, and nitrogen dynamics for two drained pine plantations under intensive management practices. Forest Ecol. Manage. 2012, 264, 20-36.

(34) Schaefer, S. C.; Alber, M. Temperature controls a latitudinal gradient in the proportion of watershed nitrogen exported to coastal ecosystems. Biogeochemistry 2007, 85 (3), 333-346.

(35) Kaushal, S. S.; Groffman, P. M.; Band, L. E.; Shields, C. A.; Morgan, R. P.; Palmer, M. A.; Belt, K. T.; Swan, C. M.; Findlay, S. E. G.; Fisher, G. T. Interaction between urbanization and climate variability amplifies watershed nitrate export in Maryland. Environ. Sci. Technol. 2008, 42 (16), 5872-5878.

(36) Murdoch, P. S.; Burns, D. A.; Lawrence, G. B. Relation of climate change to the acidification of surface waters by nitrogen deposition. Environ. Sci. Technol. 1998, 32 (11), 1642-1647.

(37) Albaugh, T. J.; Allen, H. L.; Dougherty, P. M.; Johnsen, K. H. Long term growth responses of loblolly pine to optimal nutrient and water resource availability. Forest Ecol. Manage. 2004, 192 (1), 3-19.

(38) Cairns, M. A.; Lajtha, K. Effects of succession on nitrogen export in the west-central Cascades, Oregon. Ecosystems 2005, 8 (5), $583-601$.

(39) Willett, V. B.; Reynolds, B. A.; Stevens, P. A.; Ormerod, S. J.; Jones, D. L. Dissolved organic nitrogen regulation in freshwaters. J. Environ. Qual. 2004, 33 (1), 201-209.

(40) Ros, G. H.; Hoffland, E.; van Kessel, C.; Temminghoff, E. J. M. Extractable and dissolved soil organic nitrogen - A quantitative assessment. Soil Biol. Biochem. 2009, 41 (6), 1029-1039.

(41) Qualls, R. G.; Haines, B. L. Biodegradability of dissolved organic-matter in forest throughfall, soil solution, and stream water. Soil Sci. Soc. Am. J. 1992, 56 (2), 578-586.

(42) Kalbitz, K.; Solinger, S.; Park, J. H.; Michalzik, B.; Matzner, E. Controls on the dynamics of dissolved organic matter in soils: A review. Soil Sci. 2000, 165 (4), 277-304.

(43) Jobbagy, E. G.; Jackson, R. B. The distribution of soil nutrients with depth: Global patterns and the imprint of plants. Biogeochemistry 2001, 53 (1), 51-77.

(44) Aitkenhead-Peterson, J. A.; Alexander, J. E.; Clair, T. A. Dissolved organic carbon and dissolved organic nitrogen export from forested watersheds in Nova Scotia: Identifying controlling factors. Global Biogeochem. Cycles 2005, 19 (4).

(45) Gordon, H.; Haygarth, P. M.; Bardgett, R. D. Drying and rewetting effects on soil microbial community composition and nutrient leaching. Soil Biol. Biochem. 2008, 40 (2), 302-311.

(46) Karl, T. R., Melillo, J. M., Peterson, T. C., Eds.; Global Climate Change Impacts in the United States; Cambridge University Press, 2009. 